\title{
Phosphorus availability in relation to soil properties and forest productivity in Pinus sylvestris L. plantations
}

\author{
Teresa Bueis $^{1,2}$ (D) Felipe Bravo ${ }^{1,3}$ D V Valentín Pando ${ }^{1,4}$ (D) Yaovi-Abel Kissi ${ }^{1,5}$ (D) María-Belén Turrión ${ }^{1,2}$ (D)
}

Received: 17 September 2018 / Accepted: 27 August 2019 / Published online: 18 October 2019

(C) INRA and Springer-Verlag France SAS, part of Springer Nature 2019

\begin{abstract}
- Key message Pinus sylvestris L. productivity in Spanish plantations is driven by $\mathbf{P}$ availability, which, in turn, is determined by the activity of soil microorganisms, responsible for inorganic $P$ solubilization; Fe and Al contents, responsible for $\mathbf{P}$ retention; and organic matter, which is source of organic $\mathbf{P}$, inhibits its precipitation as insoluble compounds, and reduces $P$ retention.

- Context Phosphorus is often a limiting nutrient in forest ecosystems mainly due to the low solubility of P compounds and the sorption processes occurring in soils.

- Aims The main aims of this work were to evaluate soil $\mathrm{P}$ availability, to assess which soil properties are driving $\mathrm{P}$ availability, and to study whether soil P availability is determining forest productivity in Pinus sylvestris L. plantations in Northern Spain.

- Methods Soil properties and forest productivity were studied in 34 plots located in monospecific P. sylvestris plantations. Tiessen and Moir (Canadian Society of Soil Science 75-86, 1993) sequential fractionation method was carried out to determine different forms of soil $\mathrm{P}$ and to provide a comprehensive assessment of available $\mathrm{P}$ in soils. To explore the relationships between these variables, canonical correlation analyses and Pearson's correlations were studied.

- Results Significant correlations were found between $\mathrm{P}$ fractions and soil properties related to Fe and Al contents, organic matter, and microbial biomass. Besides, significant correlations were found between site index and the studied P fractions except for $\mathrm{P}$ extracted with anion exchange membrane $\left(\mathrm{P}_{\mathrm{AEM}}\right)$ and the recalcitrant $\mathrm{P}$ fraction.

- Conclusion In the studied soils, $\mathrm{P}$ availability is low and the predominant fractions of $\mathrm{P}$ are the recalcitrant forms. Aluminum and iron contents in the soils studied play an important role in sorption processes related to the highly and moderately labile $\mathrm{P}$
\end{abstract}

This article is part of the topical collection on Mediterranean pines

Handling Editor: Andreas Bolte

Contribution of the co-authors Teresa Bueis designed the experiment, carried out the field and laboratory work except $\mathrm{P}$ fractionation, run the data analysis, discussed the results, and wrote the paper.

Felipe Bravo designed the experiment, coordinated the research project, and corrected the manuscript.

Valentín Pando supported the statistical analysis and corrected the manuscript.

Yaovi-Abel Kissi carried out part of the laboratory work (P fractionation) and corrected the manuscript.

María-Belén Turrión designed the experiment, supervised the laboratory analysis, and corrected the manuscript.

Teresa Bueis

teresa.bueis@agro.uva.es

1 Sustainable Forest Management Research Institute, University of Valladolid \& INIA, Avda. Madrid 44, 34004 Palencia, Spain

2 Departamento de Ciencias Agroforestales. E.T.S. Ingenierías Agrarias, Universidad de Valladolid, Palencia, Spain
3 Departamento de Producción Vegetal y Recursos Forestales, E.T.S. Ingenierías Agrarias, Universidad de Valladolid, Palencia, Spain

4 Departamento de Estadística e Investigación Operativa, E.T.S. Ingenierías Agrarias, Universidad de Valladolid, Palencia, Spain

5 Universidade Estadual de Mato Grosso do Sul, Dourados, Brazil 
fractions and the organic phosphorus. P availability seems to be regulated by both processes: biochemical mineralization, where phosphatase activity is relevant, and biological mineralization of the soil organic matter. Phosphorus availability affects forest productivity in the Pinus sylvestris plantations studied.

Keywords Site index $\cdot$ Phosphorus fractionation $\cdot$ Sequential extraction $\cdot$ Labile phosphorus $\cdot$ Recalcitrant phosphorus $\cdot$ Microbial biomass

\section{Introduction}

Phosphorus is known as "the key to life" because of its implication in most vital processes of organisms (Troeh and Thompson 1993) such as energy transfer, metabolic processes, and genetic codification (Marschner 1995). Phosphorus limitation is common in terrestrial ecosystems (Vitousek 1984 ) and forest productivity is also commonly P-limited (Achat et al. 2010; Bueis et al. 2016; Chen et al. 2008; Slazak et al. 2010).

Even when there is abundant total $\mathrm{P}$ in soil, $\mathrm{P}$ deficiencies are very common because it is the nutrient with the greatest problem in relation to its solubility, which is strongly dependent on the soil pH. Phosphorus in soils appears both in organic and inorganic forms. Inorganic forms of $\mathrm{P}$ in soils come from rocks as phosphates, most of which are not soluble.

Plants take up phosphates dissolved in soil solution, mainly as $\mathrm{H}_{2} \mathrm{PO}_{4}^{-}$and $\mathrm{HPO}_{4}^{2-}$. Phosphate ions can also be adsorbed by the soil anion exchange complex. The phosphates dissolved in the soil solution and those phosphates weakly adsorbed by the exchange complex are considered available for plants and microorganisms. Part of the phosphates is more strongly retained by the exchange complex and can become available in the short term. These fractions are considered labile forms of $\mathrm{P}$ (Troeh and Thompson 1993). Other forms of $P$ are included in primary Ca minerals with low solubility. Finally, the most highly recalcitrant forms of $\mathrm{P}$ are the stable forms, which are also in form of $\mathrm{Ca}$ minerals, and the residual forms, which are thought to be mainly organic forms of $\mathrm{P}$ associated with clays and $\mathrm{Fe}$ and $\mathrm{Al}$ oxides (Turrión et al. 2000b; Zamuner et al. 2008).

Organic matter plays a major role in $\mathrm{P}$ availability in forest soils. Organic matter is a direct source of available $\mathrm{P}$ in soils through the mineralization from dead organic matter and through the release from microbial biomass (Achat et al. 2010). Therefore, microbial biomass $P$ is a very active part of soil organic matter. Besides, microbial biomass has the ability to immobilize $\mathrm{P}$ when $\mathrm{P}$ availability increases acting as a nutrient pool which is released into the soil when microorganisms die (Jenkinson and Ladd 1981). Furthermore, the symbiosis established between plant roots and mycorrhizal fungi increase P uptake (da Silva et al. 2017; Desai et al. 2014). Organic matter also presents indirect effects on $P$ availability, especially in highly acidic soils. On one hand, organic matter can complex $\mathrm{Fe}$ and $\mathrm{Al}$ ions responsible for $\mathrm{P}$ precipitation as insoluble $\mathrm{Fe}$ and $\mathrm{Al}$ phosphates, reducing $\mathrm{P}$ retention in soils (Haynes and Mokolobate 2001). In addition, the organic acids originated from organic matter decomposition enhance the solubility of calcium phosphates (Troeh and Thompson 1993) and are adsorbed by $\mathrm{Fe}$ and $\mathrm{Al}$ oxides, blocking the sorption of P (Earl et al. 1979). Finally, soil microbial activities, which are responsible for the production of phosphatase enzymes that hydrolyze organic P into inorganic $\mathrm{P}$, benefit from the energy and $\mathrm{C}$ supply from organic matter (Allison and Vitousek 2005).

Pinus sylvestris L. has the widest natural distribution among pine species in the world. It extends from Western Spain to Eastern Russia and from Southern Spain to Northern Scandinavia. Therefore, Spanish stands constitute the southern and western limit of P. sylvestris distribution where it occupies more than one million hectares (Serrada et al. 2008). During the second half of the twentieth century, many Pinus plantations were carried out in Castilla y León region to recover the vegetal cover, to protect soils against erosion and to produce wood. In Castilla y León, P. sylvestris plantations occupy near 300,000 ha.

Bueis et al. (2016) found that forest productivity was related to $\mathrm{Al}$ content in soils under $P$. sylvestris plantations of the acidic plateau in the north of Castilla y León. Phosphorus availability is related to $\mathrm{Fe}$ and $\mathrm{Al}$ contents in acidic soils such as the ones under $P$. sylvestris plantations in the study area. Therefore, it is crucial to assess the relationship between $\mathrm{P}$ availability and forest productivity in these stands.

Although the general processes involved in $\mathrm{P}$ availability are known, further studies are necessary to clarify the importance of each process on specific ecosystems (Hou et al. 2014). For that purpose, the Hedley et al. (1982) P sequential fractionation method modified by Tiessen and Moir (1993) was applied in this study. This method allows the determination of the different $\mathrm{P}$ pools in soils in relation to their availability for plants and microbial uptake (Cross and Schlesinger 1995).

Our aims were (1) to assess the soil $\mathrm{P}$ availability in the soils studied, (2) to determine which soil processes are driving $P$ availability in the soils studied, and (3) to determine whether the soil $\mathrm{P}$ availability is driving forest productivity and which soil $\mathrm{P}$ fractions are the most determinant ones in the forest productivity of the stands studied. We hypothesize that (1) there is a relationship between the available forms of $\mathrm{P}$ in the forest soils studied and other labile or non-labile P fractions which may act as $\mathrm{P}$ source in the short, mid, or long term; (2) amorphous $\mathrm{Al}$ and $\mathrm{Fe}$ forms, exchangeable $\mathrm{Al}$, and 
organically bound $\mathrm{Al}$ and $\mathrm{Fe}$ in soils are the most determining soil parameters for $\mathrm{P}$ availability in the acidic soils studied; and (3) forest productivity is related to $\mathrm{P}$ availability in the P. sylvestris plantations studied.

\section{Material and methods}

\subsection{Study area and sampling plots}

The study area was located in the acidic plateau in the north of the region of Castilla y León, Spain (Annex Table 8), where 34 plots were set up covering the widest range of stand characteristics (age and stocking) in $P$. sylvestris plantations. These plots had rectangular shape $(30 \times 40 \mathrm{~m})$ and the average distance between them is $14 \mathrm{~km}$. The main characteristics of these plots are presented in Tables 1 and 2. Lithology was composed of quarzitic gravels with a sandy-clay matrix (IGME 1975). Soils were from strongly acidic to moderately acidic with loam or sandy-loam texture (Bueis et al. 2019) and were classified as Inceptisols (Herrero et al. 2016).

\subsection{Soil sampling and analysis}

Soil sampling focused on the 0 - to $10-\mathrm{cm}$ mineral topsoil. That mineral topsoil corresponds with the Ah horizon in all the studied soils. On each plot, four sampling points located 5-m distance from the center of the plot in N, S, E, and W directions were established. The four subsamples were mixed to get a composite sample per plot. Soil samples were air-dried and sieved $(2 \mathrm{~mm})$ and physical, chemical, and biochemical parameters were determined (Bueis et al. 2016) including the following: $\mathrm{pH}$ in a 1:2.5 (soil/water) suspension, using $\mathrm{pH}$ meter; soil particle size distribution (pipette method); cation exchange capacity and exchangeable acidity (Bascomb 1964); easily oxidizable C (Walkley and Black 1934); exchangeable bases (Schollenberger and Simon 1945); $\mathrm{Al}$ and $\mathrm{Fe}$ within amorphous $\mathrm{Al}$ and $\mathrm{Fe}$ oxyhydroxides (Blakemore et al. 1987); organically bound $\mathrm{Fe}$ and $\mathrm{Al}$ (Bascomb 1968); exchangeable Al (Bertsch and Bloom 1996). Biochemical parameters analyzed were microbial biomass $\mathrm{C}$ and $\mathrm{P}$ (Cmic, Pmic, Murphy and Riley 1962, Vance et al. 1987),

Table 1 Main characteristics of the plots

\begin{tabular}{lllll}
\hline Parameters & Mean & SD & Min & Max \\
\hline Elevation (m.a.s.l.) & 1069 & 72 & 926 & 1180 \\
Latitude $\left({ }^{\circ}\right)$ & 42.7 & 0.1 & 42.6 & 42.8 \\
Longitude $\left({ }^{\circ}\right)$ & -4.7 & 0.3 & -5.2 & -4.1 \\
Slope $(\%)$ & 2.4 & 3.2 & 0.0 & 12.0 \\
Total precipitation $(\mathrm{mm})$ & 738 & 79 & 597 & 943 \\
Mean annual temperature $\left({ }^{\circ} \mathrm{C}\right)$ & 9.6 & 0.4 & 8.8 & 10.4 \\
\hline
\end{tabular}

Table 2 Main characteristics of the stands

\begin{tabular}{|c|c|c|c|c|}
\hline Parameters & Mean & SD & Min & Max \\
\hline Age (years) & 39.7 & 7.4 & 28.0 & 54.0 \\
\hline Stocking (trees ha ${ }^{-1}$ ) & 1098 & 428 & 400 & 2083 \\
\hline Mean height (m) & 13.6 & 3.8 & 7.3 & 22.9 \\
\hline Basal area $\left(\mathrm{m}^{2} \mathrm{ha}^{-1}\right)$ & 32.8 & 8.2 & 16.8 & 53.6 \\
\hline Site index ( $\mathrm{m}$ at 50 years age) & 18.0 & 2.8 & 12.6 & 22.6 \\
\hline
\end{tabular}

mineralizable C (Cmin, Isermeyer 1952), and acid phosphatase activity (AcPhos; Tabatabai and Bremner 1996). More detailed information about the procedures carried out to determine microbial biomass and other biological parameters analyzed can be obtained in Bueis et al. (2018b).

Phosphorus fractionation was carried out following the method developed by Hedley et al. (1982) and modified by Tiessen and Moir (1993). The first fraction, extracted with anion exchange membranes $\left(\mathrm{P}_{\mathrm{AEM}}\right)$, is considered the readily available $\mathrm{P}$ (Turrión et al. 2008). Then, sequential extractions were carried out on the residue of the membrane extraction with progressively stronger extractants. The following extraction was carried out with $0.5 \mathrm{M} \mathrm{NaHCO}_{3}$, to determine the highly labile $\mathrm{P}$ adsorbed in the soil exchange complex (mainly to the surface of $\mathrm{Fe}$ and $\mathrm{Al}$ crystalline oxides), which can be easily transformed into available forms (Schoenau and Huang 1991; Schoenau et al. 1989; Turrión et al. 2000a). The organic and inorganic fractions of highly labile $\mathrm{P}$ were determined $\left(\mathrm{P}_{\mathrm{i}} \mathrm{NaHCO}_{3}, \mathrm{P}_{\mathrm{o}} \mathrm{NaHCO}_{3}\right)$ through the determination of total $\mathrm{P}$ in $\mathrm{NaHCO}_{3}$ extracts after digesting with $0.5 \mathrm{M} \mathrm{H}_{2} \mathrm{SO}_{4}$ and potassium persulfate at $120^{\circ} \mathrm{C}$ in an autoclave (Tiessen and Moir 1993) to transform the organic $\mathrm{P}$ into inorganic forms. The organic $\mathrm{P}$ in these extracts was determined as the difference between the total $\mathrm{P}$ and the inorganic $\mathrm{P}$. The moderately labile $\mathrm{P}$, strongly retained by chemisorption (Schoenau et al. 1989; Turrión et al. 2000a), was determined by the extraction with $0.1 \mathrm{M} \mathrm{NaOH}$ and organic and inorganic fractions were also determined to distinguish between the soil $\mathrm{P}$ associated with the humic compounds and the soil $\mathrm{P}$ adsorbed by $\mathrm{Fe}$ and Al oxides (Schoenau et al. 1989; Turrión et al. 2000b). The primary $\mathrm{P}\left(\mathrm{PHCl}_{1 \mathrm{M}}\right)$, inorganic $\mathrm{P}$ included in Ca primary minerals of low solubility (Schoenau et al. 1989; Shen et al. 2011; Turrión et al. 2000b), was extracted with $1 \mathrm{M} \mathrm{HCl}$. The most recalcitrant fractions are the stable and the residual P. The stable $\mathrm{P}\left(\mathrm{PHCl}_{\text {conc }}\right)$ was determined by the extraction with concentrated $\mathrm{HCl}$ at $90{ }^{\circ} \mathrm{C}$ and the residual $\mathrm{P}$ was extracted with $\mathrm{HClO}_{4}$ and digested at $230{ }^{\circ} \mathrm{C}$. Residual $\mathrm{P}\left(\mathrm{PHClO}_{4}\right)$ is thought to be composed of inorganic $\mathrm{P}$ tied up to amorphous $\mathrm{Fe}$ and $\mathrm{Al}$ oxides and a large proportion of resistant organic $\mathrm{P}$ associated with clay and $\mathrm{Fe}$ and $\mathrm{Al}$ oxides (Schoenau et al. 1989; Zamuner et al. 2008). For P determination in the extracts, the method by Murphy and Riley (1962) modified by Watanabe and Olsen (1965) was applied, using an ultraviolet/ 
visible spectrophotometer Hitachi U2001. The sum of the stable and the residual $P$ fractions is considered the highly recalcitrant $P$ fraction (Turrión et al. 2000b) which is also referred to as highly resistant, unavailable, refractory, or occluded forms of P (Richter et al. 2006).

\subsection{Forest productivity}

Site index (dominant height at a reference age) is a useful tool for forest productivity estimation (Skovsgaard and Vanclay 2008) and it is strongly correlated with wood production. Site index was calculated according to the equation developed by Río et al. (2006):

$$
H_{02}=\frac{40,3331}{1-\left[\left(1-\frac{40,3331}{H_{01}}\right)\left(\frac{T_{1}}{T_{2}}\right)^{1,5003}\right]}
$$

where $H_{01}$ is the current dominant height in meters (at current age $T_{1}$ ) and $H_{02}$ is the site index, the dominant height at the reference age of 50 years $\left(T_{2}\right)$. Summary of the characteristics of the plots studied is presented in Table 2.

\subsection{Statistical analyses}

To explore the relationships between $\mathrm{P}$ fractions considered (Tiessen and Moir 1993), Pearson's correlation coefficients (in R: cor.test; method: Pearson) were calculated and principal component analysis (PCA) was performed (in R: princomp). To assess the relationships between $\mathrm{P}$ fractions and soil parameters, Pearson's correlation coefficients were calculated, and canonical correlation analyses (CCA) were performed using CCA and CCP packages in R (González and Déjean 2012; Menzel 2012). The high amount of soil parameters of interest made it troublesome to interpret an only canonical correlation analysis. Therefore, canonical correlation analyses were carried out to study (a) the relationships between P fractions and soil parameters related to $\mathrm{Fe}$ and $\mathrm{Al}$, (b) $\mathrm{P}$ fractions and soil parameters related to organic matter, and (c) P fractions and soil parameters related to Ca. Finally, to study the relationships between site index (as an estimation of forest productivity) and P fractions, Pearson's correlation coefficients were calculated, and canonical correlation analysis was performed. Due to the high correlation found between the different groups of variables studied, some of them have been removed from PCA and CCA and others have been grouped together $\left(\mathrm{P}_{\mathrm{t}} \mathrm{NaHCO}_{3}\right.$ and $\left.\mathrm{P}_{\mathrm{t}} \mathrm{NaOH}\right)$. Kaiser's Measure of Sampling Adequacy (in R: KMO; psych package; Revelle 2018) was calculated to test whether the sample size was adequate or not for PCA and CCA (Cerny and Kaiser 1977). The studied variables were tested for linearity, outliers, and normality (in R: shapiro.test) and those variables not normally distributed were transformed $(\log (x)$ and $\sqrt{ } x)$ before the analyses. More specifically, the following transformations were needed to achieve normality: $\log \left(\mathrm{P}_{\mathrm{i}} \mathrm{NaHCO}_{3}\right)$, $\sqrt{\mathrm{P}_{\mathrm{o}}} \mathrm{NaHCO}_{3}, \log \left(\mathrm{P}_{\mathrm{T}} \mathrm{NaHCO}_{3}\right), \log \left(\mathrm{P}_{\mathrm{i}} \mathrm{NaOH}\right), \log \left(\mathrm{PHCl}_{1 \mathrm{M}}\right)$,

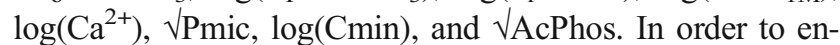
hance the readability of the results and discussion sections, we will only refer to the variables themselves in the following text, unless it affects the interpretation. Statistical analyses were performed with R software (TeamR 2015).

\section{Results}

\subsection{Phosphorus fractions and relationships between them}

Summary of the characteristics of the soils studied and their $\mathrm{P}$ fractions is shown in Tables 3 and 4, respectively (Bueis et al. 2018a).

The stable $\mathrm{P}$ fraction $\left(\mathrm{PHCl}_{\text {conc }}\right)$ is the biggest fraction in the soils studied followed by the moderately labile organic fraction. The smallest $\mathrm{P}$ fraction in these soils is the primary $\mathrm{P}$ that includes $\mathrm{P}$ forms in primary $\mathrm{Ca}$ minerals, only accounting for $2 \%$ of total $\mathrm{P}$, followed by the $\mathrm{P}_{\mathrm{AEM}}$ (less than $3 \%$ of total $\mathrm{P})$. The most recalcitrant forms of $\mathrm{P}\left(\mathrm{P}_{\mathrm{rec}}\right)$ which include the stable $\left(\mathrm{PHCl}_{\text {conc }}\right)$ and residual $\mathrm{P}\left(\mathrm{PHClO}_{4}\right)$ account for more than $42 \%$ of total $P$.

In the principal component analysis of $\mathrm{P}$ fractions, two principal components accounted for $83.4 \%$ of total variance and presented eigenvalues higher than 1. Kaiser's Measure of Sampling Adequacy (MSA) was 0.7 and, therefore, this analysis was considered statistically acceptable. The first principal component was negatively correlated to the highly labile $\mathrm{P}$ fraction $\left(\mathrm{P}_{\mathrm{t}} \mathrm{NaHCO}_{3}\right.$; Annex Table 9 and Fig. 1), the moderately labile fraction $\left(\mathrm{P}_{\mathrm{t}} \mathrm{NaOH}\right)$, and the primary $\mathrm{P}\left(\mathrm{PHCl}_{1 \mathrm{M}}\right)$. The second principal component was positively correlated to the $\mathrm{P}_{\mathrm{AEM}}$ and negatively correlated to the recalcitrant forms of $\mathrm{P}\left(\mathrm{P}_{\text {rec }}\right)$. According to the principal component analysis and the Pearson correlations (Table 5), the $\mathrm{P}_{\mathrm{AEM}}$ fraction was positively correlated to the inorganic highly labile $\mathrm{P}\left(\mathrm{P}_{\mathrm{i}} \mathrm{NaHCO}_{3}\right)$ and to the primary $\mathrm{P}\left(\mathrm{PHCl}_{1 \mathrm{M}}\right)$. The highly and moderately labile fractions were also significantly correlated with each other. Positive correlations were also found between the most recalcitrant forms of $\mathrm{P}\left(\mathrm{P}_{\mathrm{rec}}\right)$ and the organic highly labile $\left(\mathrm{P}_{\mathrm{o}} \mathrm{NaHCO}_{3}\right)$, the organic moderately labile $\mathrm{P}\left(\mathrm{P}_{\mathrm{o}} \mathrm{NaOH}\right)$, and the primary forms of $\mathrm{P}\left(\mathrm{PHCl}_{1 \mathrm{M}}\right)$.

\subsection{Relationships between $\mathrm{P}$ fractions and $\mathrm{Fe}$ and $\mathrm{Al}$ in soils}

The first two canonical factors in the canonical correlation analysis of $\mathrm{P}$ fractions and $\mathrm{Fe}$ and $\mathrm{Al}$-related parameters were significant according to Wilk's lambda test $(P<0.5)$ and presented canonical correlations of 0.86 and 0.68 , respectively. 
Table 3 Main characteristics of soils

\begin{tabular}{|c|c|c|c|c|}
\hline Soil variables & Mean & SD & Min & Max \\
\hline Clay $(\%)$ & 16.0 & 3.3 & 9.0 & 26.4 \\
\hline Sand $(\%)$ & 70.6 & 7.3 & 55.1 & 83.7 \\
\hline Silt (\%) & 13.4 & 5.2 & 6.1 & 24.5 \\
\hline $\mathrm{pH}$ & 4.5 & 0.5 & 3.7 & 5.6 \\
\hline Exchangeable acidity $\left(\mathrm{cmol}_{(+)} \mathrm{kg}^{-1}\right)$ & 13.4 & 4.6 & 5.6 & 23.6 \\
\hline Total organic $\mathrm{C} /$ total organic $\mathrm{P}$ & 1114 & 896 & 338 & 4311 \\
\hline $\mathrm{Ca}^{+2}\left(\mathrm{cmol}_{(+)} \mathrm{kg}^{-1}\right)$ & 0.9 & 0.7 & 0.2 & 2.9 \\
\hline $\mathrm{K}^{+}\left(\mathrm{cmol}_{(+)} \mathrm{kg}^{-1}\right)$ & 0.17 & 0.05 & 0.08 & 0.34 \\
\hline $\mathrm{Mg}^{+2}\left(\mathrm{cmol}_{(+)} \mathrm{kg}^{-1}\right)$ & 0.13 & 0.13 & 0.01 & 0.52 \\
\hline Cation exchange capacity $\left(\mathrm{cmol}_{(+)} \mathrm{kg}^{-1}\right)$ & 18.8 & 3.1 & 11.8 & 24.2 \\
\hline Base saturation (\%) & 7.3 & 5.3 & 2.4 & 21.1 \\
\hline Easily oxidizable carbon (\%) & 2.2 & 0.6 & 1.3 & 3.4 \\
\hline Al within amorphous oxyhydroxides $\left(\mathrm{mg} \mathrm{g}^{-1}\right)$ & 6.6 & 2.5 & 2.5 & 11.6 \\
\hline Exchangeable $\mathrm{Al}\left(\mathrm{cmol}_{(+)} \mathrm{kg}^{-1}\right)$ & 6.8 & 3.8 & 0.0 & 14.3 \\
\hline Organically bound $\mathrm{Al}\left(\mathrm{mg} \mathrm{g}^{-1}\right)$ & 9.1 & 3.9 & 2.7 & 17.9 \\
\hline Fe within amorphous oxyhydroxides ( $\mathrm{mg} \mathrm{g}^{-1}$ ) & 4.0 & 1.5 & 1.7 & 7.9 \\
\hline Organically bound $\mathrm{Fe}\left(\mathrm{mg} \mathrm{g}^{-1}\right)$ & 4.6 & 1.7 & 1.8 & 7.7 \\
\hline Microbial biomass $\mathrm{C}\left(\mathrm{mg} \mathrm{kg}^{-1}\right)$ & 113.4 & 47.4 & 45.5 & 232.9 \\
\hline Mineralizable $\mathrm{C}\left(\mathrm{mg} \mathrm{kg}^{-1}\right.$ week $\left.^{-1}\right)$ & 56.3 & 21.6 & 22.0 & 112.1 \\
\hline Microbial biomass $\mathrm{P}\left(\mathrm{mg} \mathrm{kg}^{-1}\right)$ & 11.0 & 5.8 & 4.6 & 32.2 \\
\hline Acid phosphatase activity $\left(\mu \mathrm{g} \mathrm{g}^{-1} \mathrm{~h}^{-1}\right)$ & 8.8 & 6.0 & 0.5 & 24.4 \\
\hline
\end{tabular}

$A l_{A}, F e_{A}, \mathrm{Al}$ and $\mathrm{Fe}$ within amorphous $\mathrm{Al}$ and $\mathrm{Fe}$ oxyhydroxides
Kaiser's Measure of Sampling Adequacy (MSA) was 0.77 and, therefore, this analysis was considered statistically acceptable. The first canonical factor was negatively correlated to the amorphous Fe and $\mathrm{Al}$ (Annex Table 10 and Fig. 2), the exchangeable $\mathrm{Al}$, the organically bound $\mathrm{Fe}$ and $\mathrm{Al}$, the highly labile $\mathrm{P}$ fraction $\left(\mathrm{P}_{\mathrm{t}} \mathrm{NaHCO}_{3}\right)$, and the moderately labile $\mathrm{P}$ fraction $\left(\mathrm{P}_{\mathrm{t}} \mathrm{NaOH}\right)$. The first canonical factor was also positively correlated to the readily available $\mathrm{P}$ fraction $\left(\mathrm{P}_{\mathrm{AEM}}\right)$ and

Table 4 Phosphorus fractions $\left(\mathrm{mg} \mathrm{kg}^{-1}\right)$ in soils studied

\begin{tabular}{|c|c|c|c|c|c|}
\hline $\mathrm{P}$ fractions & Mean & SD & Min & Max & $\%$ of $\mathrm{P}_{\text {Total }}$ \\
\hline $\mathrm{P}_{\mathrm{AEM}}$ & 4.0 & 1.7 & 1.4 & 7.3 & 2.6 \\
\hline $\mathrm{P}_{\mathrm{i}} \mathrm{NaHCO}_{3}$ & 5.6 & 2.9 & 2.3 & 12.2 & 3.6 \\
\hline $\mathrm{P}_{\mathrm{o}} \mathrm{NaHCO}_{3}$ & 14.7 & 7.4 & 4.5 & 37.9 & 9.5 \\
\hline $\mathrm{P}_{\mathrm{i}} \mathrm{NaOH}$ & 23.6 & 10.2 & 11.6 & 53.6 & 15.2 \\
\hline $\mathrm{P}_{\mathrm{o}} \mathrm{NaOH}$ & 37.5 & 20.9 & 0.9 & 84.7 & 24.3 \\
\hline $\mathrm{PHCl}_{1 \mathrm{M}}$ & 3.3 & 3.0 & 0.5 & 12.8 & 2.1 \\
\hline $\mathrm{PHCl}_{\text {conc }}$ & 56.1 & 22.0 & 13.8 & 101.5 & 36.3 \\
\hline $\mathrm{PHClO}_{4}$ & 9.8 & 4.1 & 2.6 & 19.1 & 6.3 \\
\hline $\mathrm{P}_{\text {Total }}$ & 154.5 & 55.5 & 59.7 & 280.7 & 100 \\
\hline
\end{tabular}

$P_{A E M}$, readily available $\mathrm{P} ; \mathrm{P}_{i} \mathrm{NaHCO}_{3}, \mathrm{P}_{\mathrm{o}} \mathrm{NaHCO}_{3}$, inorganic and organic highly labile P; $P_{o} \mathrm{NaOH}, \mathrm{P}_{i} \mathrm{NaOH}$, inorganic and organic moderately labile P; $\mathrm{PHCl}_{1 M}$, primary $\mathrm{P} ; \mathrm{PHCl}_{\text {conc }}$, stable $\mathrm{P} ; \mathrm{PHClO}_{4}$, residual P; $P_{\text {Total }}$, addition of all previous $\mathrm{P}$ fractions analyzed the primary $\mathrm{P}\left(\mathrm{PHCl}_{1 \mathrm{M}}\right)$. The recalcitrant $\mathrm{P}$ fraction $\left(\mathrm{P}_{\text {rec }}\right)$ was strongly and negatively correlated to the second canonical factor. As shown by the canonical correlation analysis (Annex Table 10 and Fig. 2) and Pearson's correlations between $\mathrm{P}$ fractions and soil $\mathrm{Fe}$ and $\mathrm{Al}$ (Table 6), the labile forms of $\mathrm{P}$ presented positive correlations with the amorphous and organically bound $\mathrm{Fe}$ and $\mathrm{Al}$ and exchangeable acidity in soils. Besides, $\mathrm{P}_{\mathrm{AEM}}$ was negatively correlated to exchangeable $\mathrm{Al}$ and positively correlated to soil $\mathrm{pH}$.

\subsection{Relationships between $P$ fractions and organic matter}

The first two canonical factors in the canonical correlation analysis of $\mathrm{P}$ fractions and organic matter-related variables were significant (Wilk's lambda test; $P<0.05$ ) and their canonical correlations were 0.87 and 0.75 respectively. Kaiser's Measure of Sampling Adequacy (MSA) was 0.55 and, therefore, this analysis was considered statistically acceptable. The first canonical factor (Annex Table 11 and Fig. 3) was negatively correlated to the easily oxidizable $\mathrm{C}$, the microbial biomass $\mathrm{C}$, the acid phosphatase activity, the highly labile $\mathrm{P}$ $\left(\mathrm{P}_{\mathrm{t}} \mathrm{NaHCO}_{3}\right)$, the moderately labile $\mathrm{P}\left(\mathrm{P}_{\mathrm{t}} \mathrm{NaOH}\right)$, and the recalcitrant $\mathrm{P}\left(\mathrm{P}_{\text {rec }}\right)$. The second canonical factor was negatively correlated to the mineralizable $\mathrm{C}\left(\mathrm{C}_{\min }\right)$, the $\mathrm{P}_{\mathrm{AEM}}$, and the primary $\mathrm{P}\left(\mathrm{PHCl}_{1 \mathrm{M}}\right)$. 


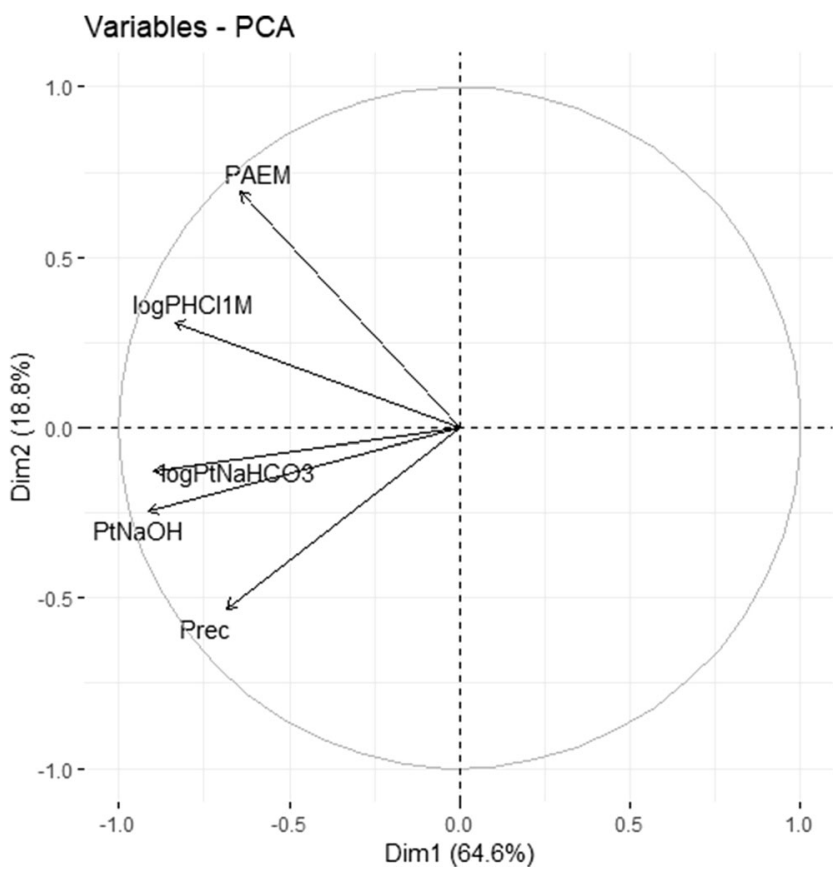

Fig. 1 Variables plot for the first (Dim1) and second (Dim2) components of the principal component analysis performed to the $\mathrm{P}$ fractions $\left(\mathrm{P}_{\mathrm{AEM}}\right.$, available $\mathrm{P} ; \mathrm{P}_{\mathrm{t}} \mathrm{NaHCO}_{3}$, highly labile $\mathrm{P} ; \mathrm{P}_{\mathrm{t}} \mathrm{NaOH}$, moderately labile $\mathrm{P}$; $\mathrm{PHCl}_{1 \mathrm{M}}$, primary $\mathrm{P} ; \mathrm{P}_{\text {rec }}$, recalcitrant $\mathrm{P}$ )

According to the canonical correlation analysis (Annex Table 11 and Fig. 3) and the Pearson correlations between $P$ fractions and organic matter-related variables (Table 6), the easily oxidizable $\mathrm{C}$ was positively correlated to the inorganic moderately labile $\mathrm{P}$ form $\left(\mathrm{P}_{\mathrm{i}} \mathrm{NaOH}\right)$. The microbial biomass $\mathrm{P}$ was positively correlated to all $\mathrm{P}$ fractions considered and microbial biomass $\mathrm{C}$ was positively correlated to all $\mathrm{P}$ fractions considered in the analysis except with $\mathrm{P}_{\mathrm{i}} \mathrm{NaHCO}_{3}$ and $\mathrm{P}_{\mathrm{i}} \mathrm{NaOH}$. Mineralizable $\mathrm{C}$ was negatively correlated to the inorganic moderately labile $\mathrm{P}$ fraction $\left(\mathrm{P}_{\mathrm{i}} \mathrm{NaOH}\right)$ and acid phosphatase activity was only correlated (positively) to the organic moderately labile $\mathrm{P}$ fraction $\left(\mathrm{P}_{\mathrm{o}} \mathrm{NaOH}\right)$.

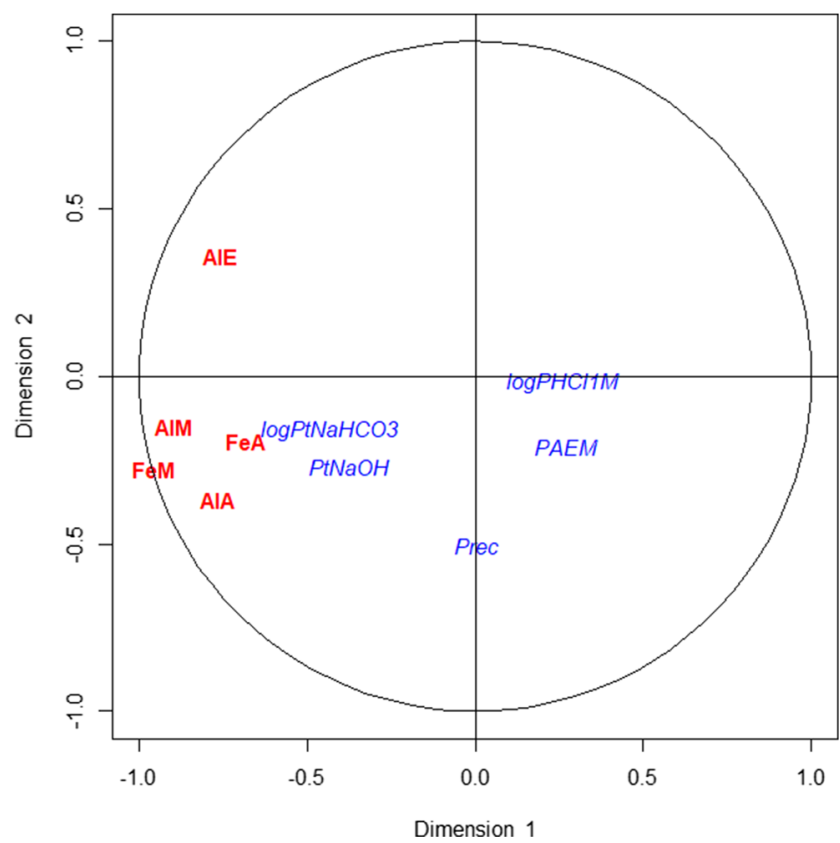

Fig. 2 Variables plot for the first and second canonical factors of the canonical correlation analysis performed to the $\mathrm{P}$ fractions and $\mathrm{Fe}$ - and Al-related variables $\left(\mathrm{Al}_{\mathrm{A}}, \mathrm{Fe}_{\mathrm{A}}, \mathrm{Al}\right.$ and $\mathrm{Fe}$ within amorphous $\mathrm{Al}$ and $\mathrm{Fe}$ oxyhydroxides; $\mathrm{Al}_{\mathrm{E}}$, exchangeable $\mathrm{Al} ; \mathrm{Al}_{\mathrm{M}}, \mathrm{Fe}_{\mathrm{M}}$, organically bound $\mathrm{Al}$ and Fe; $\mathrm{P}_{\mathrm{AEM}}$, available $\mathrm{P} ; \mathrm{P}_{\mathrm{t}} \mathrm{NaHCO}_{3}$, highly labile $\mathrm{P} ; \mathrm{P}_{\mathrm{t}} \mathrm{NaOH}$, moderately labile $\mathrm{P} ; \mathrm{PHCl}_{1 \mathrm{M}}$, primary $\mathrm{P} ; \mathrm{P}_{\text {rec }}$, recalcitrant $\mathrm{P}$ )

\subsection{Relationships between $\mathrm{P}$ fractions and $\mathrm{Ca}$}

The first two canonical factors in the canonical correlation analysis of $\mathrm{P}$ fractions and $\mathrm{Ca}$-related variables were significant (Wilk's lambda test; $P<0.05$ ) and their canonical correlations were 0.80 and 0.71 , respectively. Kaiser's Measure of Sampling Adequacy (MSA) was 0.67 and, therefore, this analysis was considered statistically acceptable. The first canonical factor (Annex Table 12 and Fig. 4) was negatively correlated to the exchangeable $\mathrm{Ca}$, the $\mathrm{P}_{\mathrm{AEM}}$, the highly labile $\mathrm{P}$ fraction $\left(\mathrm{P}_{\mathrm{t}} \mathrm{NaHCO}_{3}\right)$, the moderately labile $\mathrm{P}$ fraction $\left(\mathrm{P}_{\mathrm{t}} \mathrm{NaOH}\right)$, and the primary $\mathrm{P}\left(\mathrm{PHCl}_{1 \mathrm{M}}\right)$. The second canonical factor was positively correlated to the soil $\mathrm{pH}$ and the recalcitrant $\mathrm{P}$ fraction
Table 5 Pearson's correlations between P fractions in soils (“-”" means not significant)

\begin{tabular}{lllllll}
\hline & $\mathrm{P}_{\mathrm{AEM}}$ & $\log \left(\mathrm{P}_{\mathrm{i}} \mathrm{NaHCO}_{3}\right)$ & $\sqrt{ } \mathrm{P}_{\mathrm{o}} \mathrm{NaHCO}_{3}$ & $\log \left(\mathrm{P}_{\mathrm{i}} \mathrm{NaOH}\right)$ & $\mathrm{P}_{\mathrm{o}} \mathrm{NaOH}$ & $\log \left(\mathrm{PHCl}_{1 \mathrm{M}}\right)$ \\
\hline $\log \left(\mathrm{P}_{\mathrm{i}} \mathrm{NaHCO}_{3}\right)$ & $0.45^{* *}$ & & & & & \\
$\sqrt{\mathrm{P}_{\mathrm{o}} \mathrm{NaHCO}_{3}}$ & - & - & & & & \\
$\log \left(\mathrm{P}_{\mathrm{i}} \mathrm{NaOH}\right)$ & - & $0.62^{* * *}$ & $0.45^{* *}$ & & & \\
$\mathrm{P}_{\mathrm{o}} \mathrm{NaOH}$ & & - & $0.82^{* * *}$ & & & \\
$\log \left(\mathrm{PHCl}_{1 \mathrm{M}}\right)$ & $0.66^{* * *}$ & - & $0.54 * *$ & $0.44^{* * *}$ & $0.57 * * *$ & \\
$\mathrm{P}_{\text {rec }}$ & - & - & $0.54 * * *$ & - & $0.72 * * *$ & $0.45^{* *}$ \\
\hline
\end{tabular}

$* * P<0.01$; *** $P<0.001 . P_{A E M}$, available $\mathrm{P} ; \mathrm{P}_{i} \mathrm{NaHCO}_{3}, \mathrm{P}_{o} \mathrm{NaHCO}_{3}$, inorganic and organic highly labile P; $P_{i} \mathrm{NaOH}, \mathrm{P}_{o} \mathrm{NaOH}$, inorganic and organic moderately labile $\mathrm{P} ; \mathrm{PHCl}_{l \mathrm{M}}$, primary $\mathrm{P} ; P_{\text {rec }}$, recalcitrant $\mathrm{P}$ fraction $\left(\mathrm{PHCl}_{\text {conc }}+\mathrm{PHClO}_{4}\right)$ 
Table 6 Pearson's correlations between P fractions and physical, chemical, and biochemical parameters in soils and site index (“-” means not significant)

\begin{tabular}{|c|c|c|c|c|c|c|c|}
\hline & $\mathrm{P}_{\mathrm{AEM}}$ & $\log \left(\mathrm{P}_{\mathrm{i}} \mathrm{NaHCO}_{3}\right)$ & $\sqrt{ }\left(\mathrm{P}_{\mathrm{o}} \mathrm{NaHCO}_{3}\right)$ & $\log \left(\mathrm{P}_{\mathrm{i}} \mathrm{NaOH}\right)$ & $\mathrm{P}_{\mathrm{o}} \mathrm{NaOH}$ & $\log \left(\mathrm{PHCl}_{1 \mathrm{M}}\right)$ & $\mathrm{P}_{\mathrm{rec}}$ \\
\hline $\mathrm{pH}$ & $0.50 * *$ & - & - & - & & $0.51 * *$ & $0.50 * *$ \\
\hline $\mathrm{EOC}$ & - & & & $0.44 * *$ & & - & - \\
\hline EA & - & - & - & $0.53 * *$ & - & - & - \\
\hline $\log \left(\mathrm{Ca}^{2+}\right)$ & $0.73 * * *$ & - & - & - & $0.46^{* *}$ & $0.62 * * *$ & \\
\hline $\mathrm{Al}_{\mathrm{E}}$ & $-0.46^{* *}$ & - & - & - & - & $-0.46^{* *}$ & - \\
\hline $\mathrm{Fe}_{\mathrm{A}}$ & - & - & $0.54 * *$ & $0.45 * *$ & $0.60 * * *$ & - & - \\
\hline Cmic & $0.70 * * *$ & $0.53 * *$ & - & & $0.54 * *$ & $0.47 * *$ & \\
\hline$\sqrt{\text { Pmic }}$ & $0.60 * * *$ & & $0.49 * *$ & & $0.60 * * *$ & $0.44 * *$ & $0.44 * *$ \\
\hline $\log (\mathrm{Cmin})$ & - & - & - & $-0.51 * *$ & - & - & - \\
\hline Site index & - & $0.54 * * *$ & & $0.58 * * *$ & $0.47 * *$ & $0.50 * *$ & - \\
\hline
\end{tabular}

$* * P<0.01$; *** $\mathrm{P}<0.001 . P_{A E M}$, available $\mathrm{P} ; \mathrm{P}_{i} \mathrm{NaHCO}_{3}, \mathrm{P}_{o} \mathrm{NaHCO}_{3}$, highly labile inorganic and organic P; $\mathrm{P}_{i} \mathrm{NaOH}, \mathrm{P}_{o} \mathrm{NaOH}$, moderately labile inorganic and organic $\mathrm{P} ; \mathrm{PHCl}_{I M}$, primary $\mathrm{P} ; P_{\text {rec }}$, recalcitrant $\mathrm{P}$; $E O C$, easily oxidizable $\mathrm{C} ; E A$, exchangeable acidity; $F e_{A}$, $\mathrm{Fe}$ within amorphous Fe oxyhydroxides; $\mathrm{Al}_{E}$, exchangeable $\mathrm{Al} ; \mathrm{Cmic}$, microbial biomass $\mathrm{C}$; Pmic, microbial biomass $\mathrm{P}$; $\mathrm{Cmin}$, mineralizable $\mathrm{C}$

$\left(\mathrm{P}_{\mathrm{rec}}\right)$. According to the canonical correlation analysis (Annex Table 12 and Fig. 4) and the correlations between $\mathrm{P}$ fractions and Ca-related variables (Table 6), the $\mathrm{P}_{\mathrm{AEM}}$ fraction was positively correlated to the soil $\mathrm{pH}$ and the exchangeable $\mathrm{Ca}$. The organic moderately labile fraction of $\mathrm{P}\left(\mathrm{P}_{\mathrm{O}} \mathrm{NaOH}\right)$ and the primary $\mathrm{P}$ fraction $\left(\mathrm{PHCl}_{1 \mathrm{M}}\right)$ showed a positive correlation with $\mathrm{Ca}$ and the recalcitrant $\mathrm{P}$ fraction with the $\mathrm{pH}$.

\subsection{Relationships between soil P fractions and forest productivity}

Finally, in the canonical correlation analysis performed on $\mathrm{P}$ fractions in relation to forest productivity (estimated through the site index of stands), the only canonical factor was significant (Wilk's lambda; $P<0.05$ ) and presented a canonical correlation of 0.70. Kaiser's Measure of Sampling Adequacy
Fig. 3 Variables plot for the first and second canonical factors of the canonical correlation analysis performed to the $\mathrm{P}$ fractions and organic matter-related variables (EOC, easily oxidizable C; Cmic and Pmic, microbial biomass $\mathrm{C}$ and $\mathrm{P}$, respectively; $\mathrm{Cmin}$, mineralizable $\mathrm{C}$; AcPhos, acid phosphatase activity; $\mathrm{P}_{\mathrm{AEM}}$, available $\mathrm{P} ; \mathrm{P}_{\mathrm{t}} \mathrm{NaHCO}_{3}$, highly labile $\mathrm{P} ; \mathrm{P}_{\mathrm{t}} \mathrm{NaOH}$, moderately labile $\mathrm{P} ; \mathrm{PHCl}_{1 \mathrm{M}}$, primary $\mathrm{P} ; \mathrm{P}_{\mathrm{rec}}$, recalcitrant $\mathrm{P}$ )

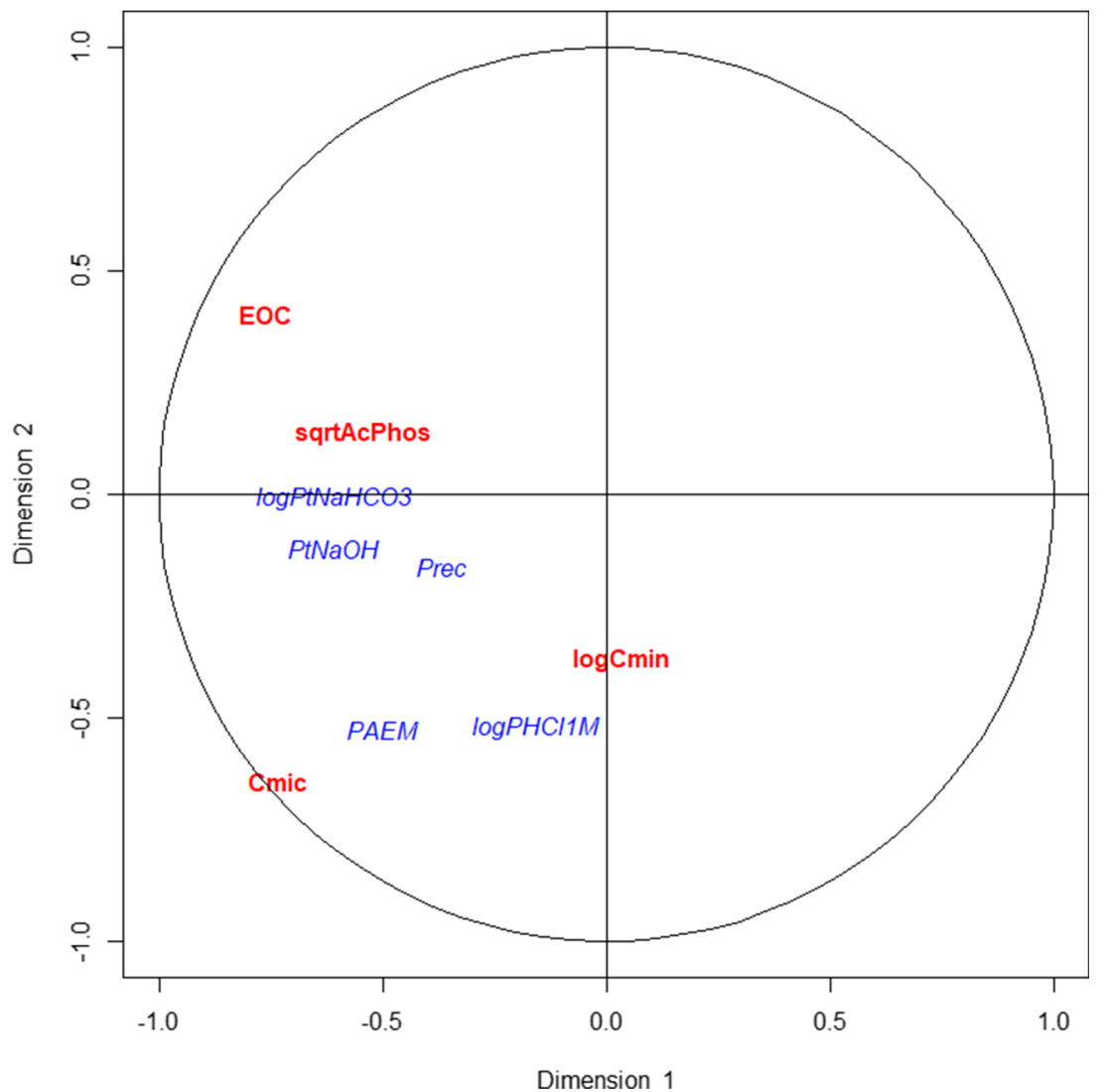


(MSA) was 0.72 and, therefore, this analysis was considered statistically acceptable. The canonical factor corresponds to the site index (Table 7) and is positively correlated to the $\mathrm{P}_{\mathrm{AEM}}$, to the highly labile $\mathrm{P}\left(\mathrm{P}_{\mathrm{t}} \mathrm{NaHCO}_{3}\right)$, to the moderately labile $\mathrm{P}\left(\mathrm{P}_{\mathrm{t}} \mathrm{NaOH}\right)$, and to the primary $\mathrm{P}\left(\mathrm{PHCl}_{1 \mathrm{M}}\right)$.

According to the canonical correlation analysis (Table 7) and the Pearson correlations (Table 6 ) between $\mathrm{P}$ fractions and site index, the site index was strongly and positively correlated to the inorganic both highly and moderately labile $\mathrm{P}$ fractions $\left(\mathrm{P}_{\mathrm{i}} \mathrm{NaHCO}_{3}, \mathrm{P}_{\mathrm{i}} \mathrm{NaOH}\right)$, the organic highly labile $\mathrm{P}$ $\left(\mathrm{P}_{\mathrm{o}} \mathrm{NaHCO}_{3}\right)$, the organic moderately labile $\mathrm{P}\left(\mathrm{P}_{\mathrm{i}} \mathrm{NaOH}\right)$, and the $\mathrm{PHCl}_{1 \mathrm{M}}$.

\section{Discussion}

\subsection{Distribution of phosphorus fractions and relationships among them}

The stable $\left(\mathrm{PHCl}_{\text {conc }}\right)$ and the organic moderately labile $\left(\mathrm{P}_{\mathrm{o}} \mathrm{NaOH}\right)$ fractions were the predominant forms of $\mathrm{P}$ in the soils studied as also observed by Turrión et al. (2007). The low soil $\mathrm{pH}$ in the soils studied is related to the presence of exchangeable Al responsible for the decrease in $\mathrm{P}$ solubility and for the increase in the non-labile $\mathrm{P}$ pools (Cross and Schlesinger 1995; Hou et al. 2014).

The positive correlations observed between the $\mathrm{P}_{\mathrm{AEM}}$ and the inorganic highly labile $\mathrm{P}\left(\mathrm{P}_{\mathrm{i}} \mathrm{NaHCO}_{3}\right)$ indicate that this fraction in the soils studied could act as source of available $P$ in the short term. Tiessen et al. (1984) found that bicarbonate extracted P explained $80 \%$ of the variability of available P. In our soils, the organic bicarbonate extractable fraction $\left(\mathrm{P}_{\mathrm{o}} \mathrm{NaHCO}_{3}\right)$ was not significantly correlated to available $\mathrm{P}$ even when this fraction includes easily exchangeable $\mathrm{P}$ compounds and it is considered a very active fraction of soil organic P (Zamuner et al. 2008). Even when the soils studied are acidic, the $\mathrm{PHCl}_{1 \mathrm{M}}$, which is associated with $\mathrm{Ca}$, was strongly correlated to $\mathrm{P}_{\mathrm{AEM}}$ indicating that this $\mathrm{P}$ fraction in primary minerals could act as source of available $\mathrm{P}$ in the mid-term (Cross and Schlesinger 1995; Richter et al. 2006). In addition, the most refractory forms of $\mathrm{P}$ were also positively correlated to organic and inorganic less resistant fractions $\mathrm{P}\left(\mathrm{P}_{\mathrm{o}} \mathrm{NaHCO}_{3}\right.$ and $\left.\mathrm{P}_{\mathrm{o}} \mathrm{NaOH}\right)$ and to primary $\mathrm{P}\left(\mathrm{PHCl}_{1 \mathrm{M}}\right)$ clarifying the role of $\mathrm{P}$ fractions with slower cycles as source of labile and available $\mathrm{P}$ in the long term (Richter et al. 2006).

\subsection{Phosphorus fractions in relation to soil properties}

In natural soils, some microorganisms are effective at releasing $\mathrm{P}$ through the mineralization of organic $\mathrm{P}$ (Bhattacharyya and Jha 2012) and the solubilization of mineral P by the production of dissolving compounds (Sharma et al. 2013). Results shown in Fig. 3 indicate that the first canonical factor of the CCA was highly correlated to the microbial biomass $\mathrm{C}$ and the acid phosphatase activity which plays an important role in the $\mathrm{P}$ biochemical mineralization where $\mathrm{P}$ is released from organic compounds regulated by $\mathrm{P}$ demand. The second canonical factor was highly correlated to the microbial biomass $\mathrm{C}$ and to the mineralizable $\mathrm{C}$ which represents the biological mineralization of $\mathrm{P}$ from organic compounds during soil organic matter oxidation by soil organisms and regulated by the energy demand. Both biochemical and biological $\mathrm{P}$ mineralization seem to be relevant in the soils studied. Acid phosphatase activity is known to be inhibited in strongly acidic soils by exchangeable Al and protons (Bueis et al. 2018b; Trasar-Cepeda and Gil-Sotres 1987) which dominate the exchange complex in the soils studied. Microbial populations not only take part in P mineralization and solubilization of soil $\mathrm{P}$ but also are a pool of organic $\mathrm{P}$, which is released when microorganisms die (Nannipieri et al. 2002). Our results showed that the microbial biomass $\mathrm{C}$ and the microbial biomass $\mathrm{P}$ were significantly correlated to $\mathrm{P}_{\mathrm{AEM}}$. Lack of consistent relationships between available $\mathrm{P}$ and phosphatase activities cannot be interpreted as lack of a role for these enzymes, because they are controlled by end product inhibition and repression by phosphate (McGill and Cole, 1981).

Organic P in Inceptisols contributes by $40-45 \%$ to total P (Yang and Post 2011); however, in the soil analyzed in our study, the organic P represented between 12 and 51\%; thus, we cannot affirm that the organic $\mathrm{P}$ amount in the studied soils is high. In addition, it has been observed that the organic $\mathrm{P}$ $\left(\mathrm{P}_{\mathrm{o}} \mathrm{NaOH}\right)$ decreases with decreasing $\mathrm{P}$ availability. Normally, high $\mathrm{C}$ to Po ratios (200 or more), as those found in the studied soils, are associated with P-deficient soils, whereas soils well supplied with available $\mathrm{P}$ have $\mathrm{C}$ to $\mathrm{Po}$ ratios which are generally $<100$ (Yang and Post 2011).

The positive correlation found between the primary $\mathrm{P}$ fraction $\left(\mathrm{PHCl}_{1 \mathrm{M}}\right)$ and $\mathrm{pH}$ and the exchangeable $\mathrm{Ca}$ indicates that this $\mathrm{P}$ pool in soils could be related to $\mathrm{Ca}$ primary minerals (Schoenau et al. 1989; Shen et al. 2011; Turrión et al. 2000a).

Correlations found between highly and moderately labile $\mathrm{P}$ fractions $\left(\mathrm{P}_{\mathrm{i}} \mathrm{NaHCO}_{3}, \mathrm{P}_{\mathrm{o}} \mathrm{NaHCO}_{3}, \mathrm{P}_{\mathrm{i}} \mathrm{NaOH}, \mathrm{P}_{\mathrm{o}} \mathrm{NaOH}\right)$ and soil parameters such as exchangeable acidity and amorphous Fe content are in accordance with the general belief that these $\mathrm{P}$ fractions are controlled by sorption processes which, in acidic soils as the ones studied, are mainly carried out by $\mathrm{Fe}$ oxides (Hedley et al. 1982; Schoenau et al. 1989). Sorption processes are considered to be the most important process controlling $\mathrm{P}$ availability in soils (Lajtha et al. 1999). Phosphate sorption maintains very low concentrations of $\mathrm{P}$ in soil solutions, particularly in mineral soils. Since sorption is reversible to some degree, sorbed $\mathrm{P}$ may be a source of plant-available $\mathrm{P}$ either immediately or in the mid or long term. However, the degree of reversibility is not well understood, and there is no single easy measurement of P sorption. The low $\mathrm{pH}$ and the high exchangeable acidity in soils studied 
Fig. 4 Variables plot for the first and second canonical factors of the canonical correlation analysis performed to the $\mathrm{P}$ fractions and calcium-related variables $(\mathrm{Ca}$, exchangeable $\mathrm{Ca} ; \mathrm{P}_{\mathrm{AEM}}$, available $\mathrm{P} ; \mathrm{P}_{\mathrm{t}} \mathrm{NaHCO}_{3}$, highly labile $\mathrm{P}$; $\mathrm{P}_{\mathrm{t}} \mathrm{NaOH}$, moderately labile $\mathrm{P}$; $\mathrm{PHCl}_{1 \mathrm{M}}$, primary $\mathrm{P} ; \mathrm{P}_{\text {rec }}$, recalcitrant $\mathrm{P}$ )

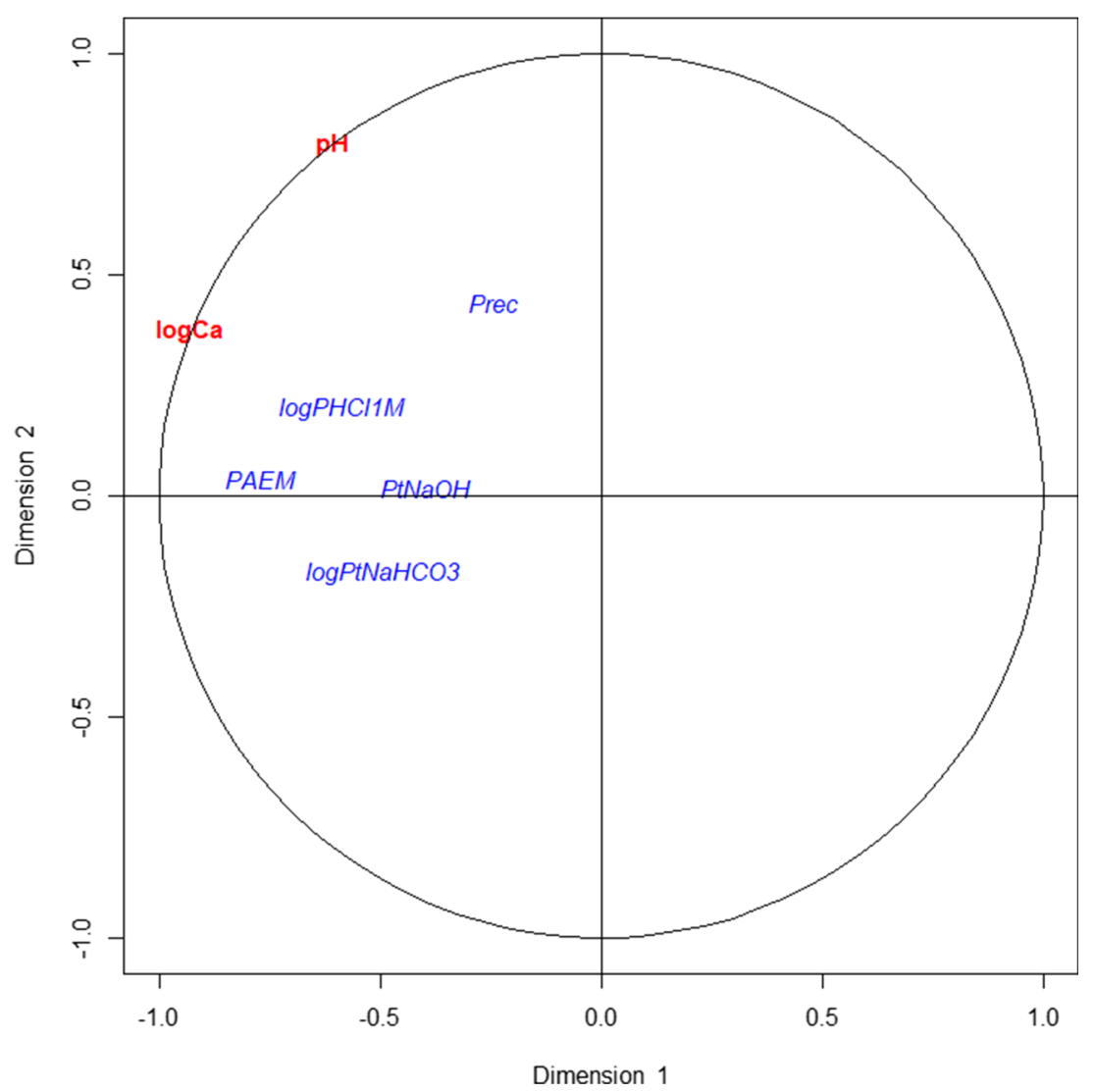

are related to high amounts of $\mathrm{Fe}$ and $\mathrm{Al}$, responsible for $\mathrm{P}$ sorption (Turrión et al. 2008). Crystalline and amorphous Fe and $\mathrm{Al}$ oxides are the main phosphate "sorbents" in acidic soils (Hsu 1989). However, amorphous Fe and Al oxides are responsible for major $\mathrm{P}$ sorption because of their high specific surface area (Achat et al. 2010). Besides, amorphous Fe and Al oxides become more reactive with soil acidification (Richter et al. 2006). Slazak et al. (2010) also found a significant and positive correlation between $\mathrm{P}_{\mathrm{i}} \mathrm{NaOH}$ and $\mathrm{Fe}$ and $\mathrm{Al}$ oxides in soils under forest stands in Germany.

Organic matter is source of available $\mathrm{P}$ by direct and indirect means. Organic matter could act as source of

Table 7 Factor loadings for canonical correlation analysis performed on site index in relation to $P$ fractions in soils

\begin{tabular}{ll}
\hline Variable & Factor 1 \\
\hline $\mathrm{P}_{\mathrm{AEM}}$ & 0.460 \\
$\log \left(\mathrm{P}_{\mathrm{t}} \mathrm{NaHCO}_{3}\right)$ & 0.857 \\
$\mathrm{P}_{\mathrm{t}} \mathrm{NaOH}$ & 0.819 \\
$\log \left(\mathrm{PHCl}_{1 \mathrm{M}}\right)$ & 0.710 \\
$\mathrm{P}_{\text {rec }}$ & 0.166 \\
Site index & 1 \\
\hline
\end{tabular}

$P_{A E M}$, readily available $\mathrm{P} ; \mathrm{P}_{t} \mathrm{NaHCO}_{3}$, highly labile $\mathrm{P} ; P_{t} \mathrm{NaOH}$, moderately labile $\mathrm{P} ; \mathrm{PHCl}_{1 M}$, primary $\mathrm{P} ; P_{\text {rec }}$, recalcitrant $\mathrm{P}$ inorganic labile $\mathrm{P}$ in the soils studied as reflected in the positive correlation found between the easily oxidizable $\mathrm{C}$ and the moderately labile inorganic $\mathrm{P}$ fractions $\left(\mathrm{P}_{\mathrm{i}} \mathrm{NaOH}\right)$. Hou et al. (2014) also found a direct relation between soil organic $\mathrm{C}$ and $\mathrm{P}$ associated with $\mathrm{Al}$ and $\mathrm{Fe}$. Besides, they observed an increment in inorganic soluble $\mathrm{P}$ and labile inorganic $\mathrm{P}$ with soil organic $\mathrm{C}$ as these soluble and labile forms of $\mathrm{P}$ come from the mineralization of the organic matter. The positive correlation found between the microbial biomass $\mathrm{P}$ and $\mathrm{P}_{\mathrm{AEM}}$ is consistent with previous studies (Zamuner et al. 2008) and with the fact that microbial biomass regulates $\mathrm{P}$ availability through the mineralization of the organic $\mathrm{P}$ and through the release of the $\mathrm{P}$ contained in their own structures after their death.

Besides, organic matter complexes $\mathrm{Fe}$ and $\mathrm{Al}$ ions blocking $\mathrm{P}$ precipitation and also occupies exchangeable sites in $\mathrm{Fe}$ and Al oxides reducing their sorption of $\mathrm{P}$ (Earl et al. 1979; Haynes and Mokolobate 2001). Organically bound Fe and Al presented positive correlations with labile $P$ fractions indicating that the higher the amount of organically bound Fe and $\mathrm{Al}$, the lower the $\mathrm{P}$ precipitation in these soils.

The recalcitrant $\mathrm{P}$ fraction $\left(\mathrm{P}_{\mathrm{rec}}\right)$ was also positively correlated to soil $\mathrm{pH}$ indicating that higher soil $\mathrm{pH}$ is related to higher amounts of $\mathrm{P}$ occluded in $\mathrm{Ca}$ compounds (Richter et al. 2006). 


\subsection{Phosphorus fractions in relation to forest productivity}

The site index of the studied plots is within the range found for P. sylvestris stands by Río et al. (2006) all over the Castilla y León region and by Palahi et al. (2004) in stands located in north-east Spain.

In the soils studied, available $\mathrm{P}$ and highly and moderately labile and primary $\mathrm{P}$ fractions were positively correlated to site index, estimator of forest productivity in the P. sylvestris plantations studied. In the short term, the available and the most labile fractions of $\mathrm{P}$ determine the productivity of ecosystems (Chen et al. 2008). However, in the mid-term, less labile $P$ fractions make important contributions to $\mathrm{P}$ availability (Cross and Schlesinger 1995; Richter et al. 2006) as reflected in the correlations found. Turrión et al. (2000a) studied the effect of P fertilization in forests located in the Spanish Central System and found a forest productivity increment after fertilization. In previous studies, Bueis et al. (2016) developed a discriminant model to predict forest site index for P. sylvestris, using the plots studied in the present work. This model included soil, climatic, and physiographic parameters. The model selected had as predictors: latitude, porosity, inorganic Al, and microbial biomass, parameters which were strongly related with precipitations and water surplus, soil water availability, phosphorus immobilization, and the turnover rate of nutrients (Bueis et al. 2016).

\section{Conclusions}

In the studied acidic soils, $\mathrm{P}$ availability for plants and microorganisms is low and the predominant fractions of $\mathrm{P}$ are the recalcitrant forms. In these soils, both biological and biochemical mineralization processes play an important role in $\mathrm{P}$ cycling. Aluminum and specially iron contents in the soils studied also provoke phosphorus immobilization processes related to the highly and moderately labile $\mathrm{P}$ fractions.

Finally, the short- and mid-term $P$ availability seems to be determinant of forest productivity in the $P$. sylvestris plantations studied as previously expected.

Acknowledgments The authors are grateful to Elisa Mellado, Temesgen Desalegn, Olga López, and Carlos Alejandro Mendoza for their assistance in the field work; to Carmen Blanco and Juan Carlos Arranz for their advice in laboratory analysis; and to Adele Muscolo for her support in phosphatase activity determination.

Funding information This work was financially supported by the Ministry of Economy and Competitiveness of the Spanish Government (AGL2011-29701-C02-02, AGL2014-51964-C2-1-R), the University of Valladolid and Banco Santander (predoctoral grant to T. BUEIS), and the Mediterranean Regional Office of the European Forest Institute (EFIMED; "Short Scientific Visit" grant to T. BUEIS).

Data availability The datasets generated during and/or analyzed during the current study are available in the Zenodo repository (Bueis et al. 2018a) at https://doi.org/10.5281/zenodo.1560581.

\section{Compliance with ethical standards}

Conflict of interest The authors declare that they have no conflicts of interest.

\section{Annex}

Table 8 Location of the plots studied. (UTM Projection in meters; Datum ETRS89) 
Table 9 Factor loadings of the principal component analysis of $\mathrm{P}$ fractions in soils

\begin{tabular}{lcc}
\hline Variable & Component 1 & Component 2 \\
\hline $\mathrm{P}_{\mathrm{AEM}}$ & -0.359 & 0.715 \\
$\log \left(\mathrm{P}_{\mathrm{t}} \mathrm{NaHCO}_{3}\right)$ & -0.500 & 0.133 \\
$\mathrm{P}_{\mathrm{t}} \mathrm{NaOH}$ & -0.509 & -0.253 \\
$\log \left(\mathrm{PHCl}_{1 \mathrm{M}}\right)$ & -0.465 & 0.320 \\
$\mathrm{P}_{\text {rec }}$ & -0.381 & -0.551 \\
\hline
\end{tabular}

$P_{A E M}$, available P; $\mathrm{P}_{t} \mathrm{NaHCO}_{3}$, highly labile P; $\mathrm{P}_{t} \mathrm{NaOH}$, moderately labile $\mathrm{P} ; \mathrm{PHCl}_{I M}$, primary $\mathrm{P} ; P_{r e c}$, recalcitrant $\mathrm{P}$ fraction

\begin{tabular}{lrr}
\hline & Factor 1 & Factor 2 \\
\hline $\mathrm{Al}_{\mathrm{A}}$ & -0.765 & -0.367 \\
$\mathrm{Al}_{\mathrm{E}}$ & -0.758 & 0.360 \\
$\mathrm{Al}_{\mathrm{M}}$ & -0.897 & -0.148 \\
$\mathrm{Fe}_{\mathrm{A}}$ & -0.681 & -0.195 \\
$\mathrm{Fe}_{\mathrm{M}}$ & -0.956 & -0.276 \\
$\mathrm{P}_{\mathrm{AEM}}$ & 0.315 & -0.311 \\
$\log \left(\mathrm{P}_{\mathrm{t}} \mathrm{NaHCO}_{3}\right)$ & -0.505 & -0.236 \\
$\mathrm{P}_{\mathrm{t}} \mathrm{NaOH}$ & -0.439 & -0.395 \\
$\log \left(\mathrm{PHCl}_{1 \mathrm{M}}\right)$ & 0.300 & -0.026 \\
$\mathrm{P}_{\text {rec }}$ & 0.006 & -0.740 \\
\hline
\end{tabular}

$A l_{A}, F e_{A}$, amorphous $\mathrm{Al}$ and $\mathrm{Fe} ; A l_{E}$, exchangeable Al; $A l_{M}, F e_{M}$, organically bound $\mathrm{Al}$ and Fe; $P_{A E M}$, readily available $\mathrm{P}$ extracted with anion exchange membranes; $\mathrm{P}_{t} \mathrm{NaHCO}_{3}$, highly labile P; $P_{t} \mathrm{NaOH}$, moderately labile P; $\mathrm{PHCl}_{I M}$, primary $\mathrm{P} ; P_{r e c}$, recalcitrant $\mathrm{P}$

Table 11 Factor loadings (simple correlations between each canonical factor and the variables) of canonical correlation analysis performed on $\mathrm{P}$ fractions in relation to organic matter in soils

\begin{tabular}{lrr}
\hline & Factor 1 & Factor 2 \\
\hline EOC & -0.759 & 0.405 \\
$\mathrm{Cmic}$ & -0.733 & -0.640 \\
$\log (\mathrm{Cmin})$ & 0.034 & -0.368 \\
$\sqrt{\mathrm{AcPhos}}$ & -0.542 & 0.138 \\
$\mathrm{P}_{\mathrm{AEM}}$ & -0.572 & -0.704 \\
$\log \left(\mathrm{P}_{\mathrm{t}} \mathrm{NaHCO}_{3}\right)$ & -0.697 & -0.011 \\
$\mathrm{P}_{\mathrm{t}} \mathrm{NaOH}$ & -0.697 & -0.158 \\
$\log \left(\mathrm{PHCl}_{1 \mathrm{M}}\right)$ & -0.183 & -0.695 \\
$\mathrm{P}_{\text {rec }}$ & -0.422 & -0.214 \\
\hline
\end{tabular}

$E O C$, easily oxidizable $\mathrm{C}$; $\mathrm{Cmic}$, microbial biomass $\mathrm{C}$; $\mathrm{Cmin}$, mineralizable $\mathrm{C}$; AcPhos, acid phosphatase activity; $P_{A E M}$, available P; $\mathrm{P}_{t} \mathrm{NaHCO}_{3}$, highly labile P; $P_{t} \mathrm{NaOH}$, moderately labile $\mathrm{P} ; \mathrm{PHCl}_{I M}$, primary $\mathrm{P} ; P_{r e c}$, recalcitrant $\mathrm{P}$
Table 12 Factor

loadings (simple correlations between each canonical factor and the variables) of canonical correlation analysis performed on $\mathrm{P}$ fractions in relation to $\mathrm{Ca}$ in soils

\begin{tabular}{llr}
\hline & Factor 1 & Factor 2 \\
\hline $\log \left(\mathrm{Ca}^{2+}\right)$ & -0.927 & 0.375 \\
$\mathrm{pH}$ & -0.606 & 0.796 \\
$\mathrm{P}_{\mathrm{AEM}}$ & -0.956 & 0.052 \\
$\log \left(\mathrm{P}_{\mathrm{t}} \mathrm{NaHCO}_{3}\right)$ & -0.614 & -0.242 \\
$\mathrm{P}_{\mathrm{t}} \mathrm{NaOH}$ & -0.497 & 0.025 \\
$\log \left(\mathrm{PHCl}_{1 \mathrm{M}}\right)$ & -0.732 & 0.280 \\
$\mathrm{P}_{\text {rec }}$ & -0.303 & 0.614 \\
\hline $\mathrm{Ca}^{+2}$, exchangeable calcium; $P_{A E M}$, avail- \\
able $\mathrm{P} ; P_{t} N a H C \mathrm{O}_{3}$, highly labile $\mathrm{P} ;$ \\
$P_{t} \mathrm{NaOH}$, moderately labile $\mathrm{P} ; \mathrm{PHCl}_{1 M}$, \\
primary $\mathrm{P} ; P_{\text {rec }}$, recalcitrant $\mathrm{P}$
\end{tabular}

\section{References}

Achat DL, Bakker MR, Zeller B, Pellerin S, Bienaime S, Morel C (2010) Long-term organic phosphorus mineralization in Spodosols under forests and its relation to carbon and nitrogen mineralization. Soil Biol Biochem 42:1479-1490. https://doi.org/10.1016/j.soilbio. 2010.05.020

Allison SD, Vitousek PM (2005) Responses of extracellular enzymes to simple and complex nutrient inputs. Soil Biol Biochem 37:937-944. https://doi.org/10.1016/j.soilbio.2004.09.014

Bascomb CL (1964) Rapid method for the determination of cation exchange capacity of calcareous and non-calcareous soils. J Sci Food Agric 15:821-823

Bascomb CL (1968) Distribution of pyrophosphate-extractable iron and organic carbon in soils of various groups. J Soil Sci 19:251-268

Bertsch PM, Bloom PR (1996) Aluminum. In: Sparks DL et al (eds) Methods of soil analysis part 3-chemical methods. vol methodsofsoilan3. SSSA, Madison, Wisconsin (USA), pp 517-550

Bhattacharyya PN, Jha DK (2012) Plant growth-promoting rhizobacteria (PGPR): emergence in agriculture. World J Microbiol Biotechnol 28:1327-1350. https://doi.org/10.1007/s11274-011-0979-9

Blakemore LC, Searle PL, Daly BK (1987) Methods for chemical analysis of soils. NZ Soil Bureau Scientific Report 80:71-76

Bueis T, Bravo F, Pando V, Turrión MB (2016) Relationship between environmental parameters and Pinus sylvestris $\mathrm{L}$. site index in forest plantations in northern Spain acidic plateau. iForest 9:394-401. https://doi.org/10.3832/ifor1600-008

Bueis T, Bravo F, Pando V, Kissi YA, Turrión MB (2018a) Phosphorus fractions and related properties in soils under Pinus sylvestris L. plantations in Spain. V1. Zenodo. [Dataset]. https://doi.org/10. 5281/zenodo.1560581

Bueis T, Turrión M-B, Bravo F, Pando V, Muscolo A (2018b) Factors determining enzyme activities in soils under Pinus halepensis and Pinus sylvestris plantations in Spain: a basis for establishing sustainable forest management strategies. Ann For Sci 75:34. https://doi. org/10.1007/s13595-018-0720-z

Bueis T, Turrión MB, Bravo F (2019) Stand and environmental data from Pinus halepensis Mill. and Pinus sylvestris L. plantations in Spain. Annals of Forest Science (accepted). https://doi.org/10.1007/ s13595-019-0810-6

Cerny BA, Kaiser HF (1977) Study of a measure of sampling adequacy for factor-analytic correlation matrices. Multivariate Behav Res 12: 43-47. https://doi.org/10.1207/s15327906mbr1201_3 
Chen CR, Condron LM, Xu ZH (2008) Impacts of grassland afforestation with coniferous trees on soil phosphorus dynamics and associated microbial processes: a review. Forest Ecol Manag 255:396-409. https://doi.org/10.1016/j.foreco.2007.10.040

Cross AF, Schlesinger WH (1995) A literature-review and evaluation of the Hedley fractionation - applications to the biogeochemical cycle of soil-phosphorus in natural ecosystems. Geoderma 64:197-214. https://doi.org/10.1016/0016-7061(94)00023-4

da Silva EP, Ferreira PAA, Furtini-Neto AE, Soares C (2017) Arbuscular mycorrhiza and phosphate on growth of Australian red cedar seedlings. Cienc Florest 27:1269-1281. https://doi.org/10.5902/ 1980509830320

Desai S, Naik D, Cumming JR (2014) The influence of phosphorus availability and Laccaria bicolor symbiosis on phosphate acquisition, antioxidant enzyme activity, and rhizospheric carbon flux in Populus tremuloides. Mycorrhiza 24:369-382. https://doi.org/10. 1007/s00572-013-0548-1

Earl KD, Syers JK, McLaughlin JR (1979) Origin of the effect of citrate, tartrate and acetate on phosphate sorption by soils and synthetic gels. Soil Sci Soc Am J 43:674-678

González I, Déjean S (2012) CCA: canonical correlation analysis. R package version 1.2

Haynes RJ, Mokolobate MS (2001) Amelioration of Al toxicity and P deficiency in acid soils by additions of organic residues: a critical review of the phenomenon and the mechanisms involved. Nutr Cycl Agroecosyst 59:47-63. https://doi.org/10.1023/a:1009823600950

Hedley MJ, Stewart JWB, Chauhan BS (1982) Changes in organic and inorganic soil phosphorus fractions induced by cultivation practices and by laboratory incubations. Soil Sci Soc Am J 46:970-976. https://doi.org/10.2136/sssaj1982.03615995004600050017x

Herrero C, Turrión MB, Pando V, Bravo F (2016) Carbon content of forest floor and mineral soil in Mediterranean Pinus spp. and oak stands in acid soils in Northern Spain. Forest Systems 25(Issue 2): e065. https://doi.org/10.5424/fs/2016252-09149

Hou EQ, Chen CR, Wen DZ, Liu X (2014) Relationships of phosphorus fractions to organic carbon content in surface soils in mature subtropical forests, Dinghushan, China. Soil Res 52:55-63

Hsu PH (1989) Aluminum oxides and oxyhidroxides. In: Dixon JB, Weed SB (eds) Minerals in soil environments. Soil Science Society of America Journal, Madison, Wisconsin, pp 99-143

IGME (1975) Mapa Geológico de España. Escala 1/50 000. Instituto Geológico y Minero de España

Isermeyer H (1952) Eine einfache Methode sur Bestimmung der Bodenatmung und der Carbonate im Boden. Zeitschrift Pflanzenernährung und Bodenkunde 56:26-38

Jenkinson DS, Ladd JN (1981) Microbial biomass in soils: measurement and turnover. In: Paul EA, Ladd JN (eds) Soil biochemistry, vol 5. Marcel Dekker, New York, pp 415-417

Lajtha K, Driscoll CT, Jarrell WM, Elliott ET (1999) Soil phosphorus: characterization and total element analysis. In: Standard soil methods for long-term ecological research. Oxford University Press, New York, pp 115-142

Marschner H (1995) Mineral nutrition of higher plants. Academic Press, London

McGill WB, Cole CV (1981) Comparative aspects of cycling of organic C, N, S and P through soil organic matter. Geoderma 26:267-286. https://doi.org/10.1016/0016-706181900240

Menzel U (2012) CCP: significance tests for canonical correlation analysis (CCA). R package version 1.1

Murphy J, Riley JP (1962) A modified single solution method for the determination of phosphorus in natural waters. Anal Chim Acta 27: 31-36. https://doi.org/10.1016/s0003-2670(00)88444-5

Nannipieri P, Kandeler E, Ruggiero P (2002) Enzyme activities and microbiological and biochemical processes in soil. In: Burns RG, Dick RP (eds) Enzymes in the environment. Marcel Dekker, New York, pp $1-33$
Palahi M, Tome M, Pukkala T, Trasobares A, Montero G (2004) Site index model for Pinus sylvestris in north-east Spain. Forest Ecol Manag 187:35-47. https://doi.org/10.1016/s0378-1127(03)00312-8

Revelle W (2018) psych: procedures for personality and psychological research. $\mathrm{R}$ package version 1.8.12

Richter DD, Allen HL, Li JW, Markewitz D, Raikes J (2006) Bioavailability of slowly cycling soil phosphorus: major restructuring of soil $\mathrm{P}$ fractions over four decades in an aggrading forest. Oecologia 150:259-271. https://doi.org/10.1007/s00442006-0510-4

Río M, López E, Montero G (2006) Manual de gestión para masas procedentes de repoblación de Pinus pinaster Ait., Pinus sylvestris L. y Pinus nigra Arn. Consejería de Medio Ambiente. Junta de Castilla y León, Castilla y León. Spain

Schoenau JJ, Stewart JWB, Bettany JR (1989) Forms and cycling of phosphorus in prairie and boreal forest soils. Biogeochemistry 8 : 223-237

Schoenau JJ, Huang WZ (1991) Anion-exchange membrane, water and sodium bicarbonate extractions as soil tests for phosphorus. Communications in Soil Science and Plant Analysis. 22: 465-492. https://doi.org/10.1080/00103629109368432

Schollenberger CJ, Simon RH (1945) Determination of exchange capacity and exchangeable bases in soil-ammonium acetate method. Soil Sci 59:13-24. https://doi.org/10.1097/00010694-19450100000004

Serrada R, González GM, Reque JA (2008) Compendio de Selvicultura aplicada en España. Instituto Nacional de Investigación y Tecnología Agraria y Alimentaria, Madrid, Spain

Sharma SB, Sayyed RZ, Trivedi MH, Gobi TA (2013) Phosphate solubilizing microbes: sustainable approach for managing phosphorus deficiency in agricultural soils. Springerplus 2:587-600. https://doi. org/10.1186/2193-1801-2-587

Shen J, Yuan L, Zhang J, Li H, Bai Z, Chen X, Zhang W, Zhang F (2011) Phosphorus dynamics: from soil to plant. Plant Physiol 156:9971005. https://doi.org/10.1104/pp.111.175232

Skovsgaard JP, Vanclay JK (2008) Forest site productivity: a review of the evolution of dendrometric concepts for even-aged stands. Forestry 81:13-31

Slazak A, Freese D, Matos ED, Huttl RF (2010) Soil organic phosphorus fraction in pine-oak forest stands in Northeastern Germany. Geoderma 158:156-162. https://doi.org/10.1016/j.geoderma.2010. 04.023

Tabatabai MA, Bremner JM (1969) Use of p-nitrophenyl phosphate for assay of soil phosphatase activity. Soil BiolBiochem 1:30. https:// doi.org/10.1016/0038-0717(69)90012-11-307

TeamR RC (2015) A language and environment for statistical computing. R Foundation for Statistical Computing, Vienna, Austria

Tiessen H, Moir JO (1993) Characterization of available P by sequential extraction. In: Carter MR (ed) Soil sampling and methods of analysis. Canadian Society of Soil Science. Lewis publishers, Boca Raton, pp 75-86

Tiessen H, Stewart JWB, Cole CV (1984) Pathways of phosphorus transformations in soils of differing pedogenesis. Soil Sci Soc Am J 48: 853-858

Trasar-Cepeda MC, Gil-Sotres F (1987) Phosphatase activity in acid high organic matter soils in Galicia (NW Spain). Soil Biol Biochem 19: 281-287. https://doi.org/10.1016/0038-0717(87)90010-1

Troeh FR, Thompson LM (1993) Soils and soil fertility, Fifth edn. Oxford University Press Inc., New York

Turrión MB, Gallardo JF, Gonzalez MI (2000a) Distribution of P forms in natural and fertilized forest soils of the central western Spain: plant response to superphosphate fertilization. Arid Soil Res Rehabil 14: 159-173. https://doi.org/10.1080/089030600263085

Turrión MB, Glaser B, Solomon D, Ni A, Zech W (2000b) Effects of deforestation on phosphorus pools in mountain soils of the Alay 
Range, Khyrgyzia. Biol Fertil Soils 31:134-142. https://doi.org/10. 1007/s003740050636

Turrión M-B, Lopez O, Lafuente F, Mulas R, Ruiperez C, Puyo A (2007) Soil phosphorus forms as quality indicators of soils under different vegetation covers. Sci Total Environ 378:195-198. https://doi.org/ 10.1016/j.sciotenv.2007.01.037

Turrión M-B, Schneider K, Gallardo JF (2008) Soil P availability along a catena located at the Sierra de Gata Mountains, Western Central Spain. Forest Ecol Manag 255:3254-3262. https://doi.org/10.1016/ j.foreco.2008.01.076

Vance ED, Brookes PC, Jenkinson DS (1987) An extraction method for measuring soil microbial biomass-C. Soil Biol Biochem 19:703707. https://doi.org/10.1016/0038-0717(87)90052-6

Vitousek PM (1984) Literfall, nutrient cycling, and nutrient limitation in tropical forest. Ecol Lett 65:285-298

Walkley A, Black IA (1934) An examination of the Degtjareff method for determining soil organic matter, and a proposed modification of the chromic acid titration method. Soil Sci 37:29-38. https://doi.org/10. 1097/00010694-193401000-00003

Watanabe FS, Olsen SR (1965) Test of an ascorbic acid method for determining phosphorus in water and $\mathrm{NaHCO}_{3}$ extracts from soil. Soil Sci Soc Am Proc 29:677-678

Yang X, Post WM (2011) Phosphorus transformations as a function of pedogenesis: a synthesis of soil phosphorus data using Hedley fractionation method. Biogeosciences 8:2907-2916. https://doi.org/10. 5194/bg-8-2907-2011

Zamuner EC, Picone LI, Echeverria HE (2008) Organic and inorganic phosphorus in Mollisol soil under different tillage practices. Soil Tillage Res 99:131-138. https://doi.org/10.1016/j.still.2007.12.006

Publisher's note Springer Nature remains neutral with regard to jurisdictional claims in published maps and institutional affiliations. 